\title{
Development of Regional Airports in Poland
}

\author{
Prof. Eng. Beata Ślusarczyk \\ Ph.D. Częstochowa University of Technology, The Management Faculty \\ Email: jagoda@zim.pcz.pl \\ Magdalena Baryń \\ M.Sc. Częstochowa University of Technology, The Management Faculty \\ Email: magdabaryn@op.pl
}

Doi:10.5901/mjss.2016.v7n4p

\begin{abstract}
In Poland, for many years the access to air transport for the average citizen was very limited, both in terms of cost and distance from the airport. After the liberalization of the aviation market and the introduction of the policy of "open skies" this situation has, however, changed dramatically. The emergence of low-cost carriers definitely increased the availability of air transport in financial terms. It had also a great influence on the development of regional airports, which so far played only a subordinate role in relation to the country's central airport in Warsaw airport. The development of regional airports largely removed the territorial limitation of the availability of air transport, since it is from these ports that you can now get to many parts of Europe and the world. Therefore, we are now seeing a continuous increase in the significance of regional airports. This trend concerns not only Poland, but also many other European countries. The purpose of this article is to determine the degree of development of regional airports in Poland and an indication of their role in the country's aviation market against the background of trends in air transport in selected EU countries.
\end{abstract}

Keywords: regional airports, airports in Poland, regional airports development

\section{Brief characteristics of airports, including the role of regional airports}

The main task of airports is the handling of passengers and cargo, and to enable a safe take-off and landing of the aircrafts, using airport services (Litwiński, 2009). Besides the transport function performed by the airports, the functions of airports can also include the promotion and development of the city and region where the port is located, income generation from both the aviation activities and additional services, job creation, trainings for employees, ensuring safety and health (air, sanitary and fire) (Czecharowski, 2002; Olebogeng \& Olebogeng, 2013). The European Commission in its Community communication guidelines on financing of airports and state aid for start-up airlines departing from regional airports on 9 December 2005, distinguishes four categories of airports: large community airports (e.g. London-Heathrow, Paris-Charles de Gaulle), national airports (e.g. Warszawa-Okecie), a large regional airports (e.g. Balice) and small regional airports (e.g. Szczecin Goleniów) (Szymonik, 2013).

A huge impact on the functioning of airports have carried out liberalization of the aviation market in Western Europe at the end of the last century. It resulted in the emergence of low-cost carriers, who have become the main force behind the development of the aviation market in many countries. These carriers particularly quickly began to develop after 2001, and in 2005 worked on the European market for more than 50 carriers of this type (Graham \& Shaw, 2008). In Poland due process later and was connected with the necessity of implementation of EU law in connection with the Polish accession to the European Union. More information about EU law and its supremacy over national law writes e.g. Anduena Gjevori (2013).

Carriers LCC (low-cost carriers) give impetus to the development of regional airports. This development in individual countries is carried out at different speeds, which results from the specific circumstances of the country, such as the ownership of airports and their management. In general, airports may be managed as a part of the national (or regional) networks or can operate independently. They may constitute a public property, private or public-private, the management of which may rest in the hands of local authorities, or may be entrusted to private companies (Halpern \& Pagliari, 2007). As examples of different approaches of states to this matter, can serve Spain, France and the United Kingdom. 
In Spain we have to deal with the centralization of ownership and management of airports. For this purpose, the organization AENA (Aeropuertos Espanoles y ón Navegaci Aérea) was brought to life was which is dependent on the Ministry of Development and manages 47 airports, including the largest ones in Madrid and Barcelona. In 2010 it introduced a reform that would contribute to the decentralization of airport management. It provides the opportunity of the partial privatization of AENA (49\% of shares) and the airports of Barajas and El Prat Airport. In 2012, the privatization of the two largest airports was withdrawn. Maintaining centralized management was supported, among others, with the argument of the possibility of covering the losses of some airports with the profits generated by other airports. Because of this, the Spanish airports do not have the tools to increase their competitiveness independently. Regional authorities are trying to support the airports situated in their territory, but in the absence of the possibility to decide on the matters of airports, it is difficult (Ballart \& Güell, 2015; Núnez-Sánchez, 2015). In recent years, outside the official system managed by AENA, private regional airports, promoted by the local authorities, have been created. Examples of such airports are at least Ciudad Real, Lleida and Murcia (Gomez Comendador, Arnaldo Valde \& Perez Sanz, 2012). More on the Spanish regional airports and their relationships with LCC carriers say Suau-Sanchez and Burghouwt (2011).

In France, until recently, all airports were public entities, jointly managed. In 2004, however, it was decided to decentralize their management, assigning each a separate manager of the airport functioning at the regional level. The transfer of airports to the regions was held free of charge. From that moment, each airport has to handle itself, starting with the possibility of closure, if it is unprofitable. The development of various regional airports takes place at different rates - some of them quickly increase their productivity, a part of them keeps it at a constant level, and a part of them reduced it (Barros, Liang \& Peypoch, 2013).

United Kingdom was the first country in Europe which began to privatize airports. This took place in 1987 (under the Airport Act of 1986.), When 7 airports (Heathrow, Gatwick, Stansted, Southampton, Edinburgh, Glasgow and Prestwick) were put under the administration of British Airports Authority (BAA). It was considered that these airports are to be financially self-sufficient units operating on a commercial basis. Airport Act allowed municipalities to privatize airports. Under second part of Airpotr Act, another 16 airports were privatized. In 2010, in UK there operated 6 airports owned by BAA, 4 airports owned by local authorities, 12 privately-owned airports, 5 public-private airports and one airport owned by local authorities managed under a concession contract (Humphreys \& Francis, 2002; Ison, Francis, Humphreys \& Page, 2011).

Regional airports are selected by LCC carriers due to such advantages as lower airport charges, shorter operative time, less traffic congestion, lack of accessibility problems and congestion, so there are no costs of delayed flights, low marginal costs and the ability to adapt infrastructure port to the needs of the carrier (Barbot, 2006; Tapiador, Mateos \& Marti-Henneberg, 2008). Regional airports can bring a lot of good not only for carriers, the airport and the users but also for the entire community (e.g. by increasing employment). Regional airports with increasing demand for air services play and will play an increasingly important role in European air network. On the one hand, they give access to air transport to more people, especially those who could not use these services in other cases. On the other hand, regional airports, because of their potential attractiveness for many carriers, increase competition between the lines, leading to lower fares, increased frequency of flights and access to more destinations (Carballo-Cruz, 2014; Karas \& Ferencova, 2010; Postorino, 2010). In the development of regional airports, a very important factor is the level of integration with the regional transport network. It is obvious that better opportunities will have the port connected with the motorway or railway

lines. The Ministry of Transportation identifies four levels of integration of the airport with the regional transport network:

- the highest level of integration show the airports connected to the motorway and having high-speed rail station,

- another level occupy ports integrated into the local rail network and main roads,

- the third level of integration we find airports connected to the main roads, having also local railway connections with supported cities;

- at the lowest level of integration are the airports communicated with the environment only by routes that do not belong to the category of highways (Kot, 2015; Augustyniak, 2012).

\section{Airports in Poland}

In Poland, according to the register of civil airports, carried out in accordance with the Aviation Law and the Regulation of the Minister of Transport, Construction and Maritime Economy, prepared by the Civil Aviation Authority in 2015 there were 59 airports. Among these are 13 airports that can handle international traffic. The biggest and at the same time central airport in Poland is Warsaw-Okecie port, but in the scale of European Union countries this port has only minor significance (Rekowski, 2011). The other 12 airports are regional ports. 
Analyzing activity of airports in Poland, and more widely - of the entire passenger air transport in this country, it is impossible not to confront it with the GDP and outcomes of the tourist industry. As the main macroeconomic gauge of states the GDP constitutes a point of reference for all industries. Next a transport and also air transport is one of bases of tourism. For these reasons it is possible to suppose that number of passengers transported by using air transport is tied together both with the level of the GDP of the country, as well as the volume of sales generated by tourism. The confirmation of these speculations can be found in coefficients of correlation determining power of the bond between categories. The coefficient of correlation of the GDP and number of passengers in air transport amounts 0,96, what marks that between these two values a very strong relation exists. It is nothing strange, because increasing the air traffic is being postponed for increasing the GDP of the country, next the rise in the economic development of the country is being transferred practically into all aspects of social-economic life, in it also for increasing the availability of the air transport. Also a very strong relation links the number of passengers in air transport with the tourist economy - in this case the coefficient of correlation achieves the value of 0,92 . Here connections also seem obvious. Air transport is the fastest type of transport, which in a short time lets reaching even into faraway corners of the world. It causes that in the foreign tourism it is a most willingly chosen way of relocating. And so the development of that kind of tourism causes the increased demand for air transport services.

The Polish airports carry out both regular and charter air traffic. The number of passengers handled by the Polish airports in years 2005-2020 is shown in Figure 1.

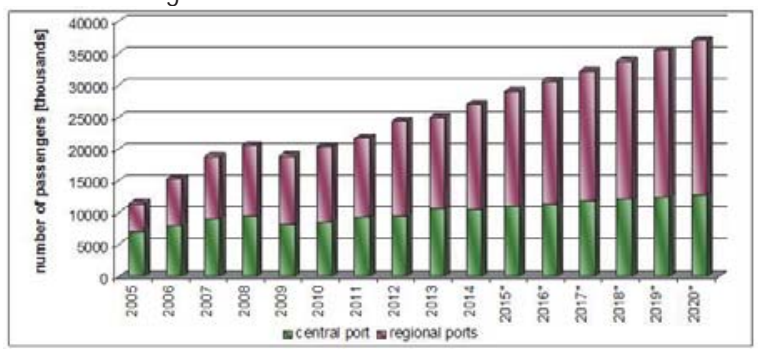

Figure 1: The number of passengers handled by the Polish airports in years 2005-2020 (for years 2015-2020 there are the forecast values)

Source: Own elaboration based on ULC data.

The number of passengers using scheduled aircrafts is steadily increasing. The exception was here only in 2009, when a decline in passenger numbers both at the port headquarters and at regional airports was recorded. The fall in prices was caused by the economic crisis, which began in 2008. In 2014 in total, Polish airports handled over 27 million passengers, which is 16 million more than 10 years earlier. A special part in this growth played regional airports where the number of passengers handled in 10 years almost quadrupled. In the central port the increase was much lower, and equalled about $50 \%$.

It is also worth noting that since 2007 the regional airports have handled more passengers than the central airport. As shown in the data, regional airports play an increasingly important role in the air transport in Poland.

If current trends and the rate of growth are kept, in 2020 over $37 \mathrm{~m}$ passengers will be handled by Polish airports, and almost $65 \%$ of them will use regional ports. Forecasts also show that the development of regional ports will be much faster and more intense than the development of the central port. Figure 2 shows the contribution of individual ports to the overall structure of the number of passengers handled at airports in Poland in 2014.

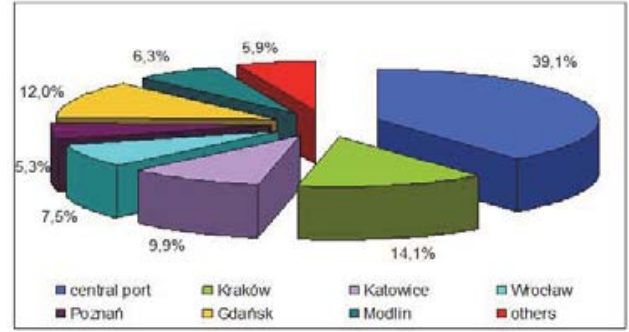

Figure 2: Structure of the number of passengers served at Polish airports in 2014.

Source: Own elaboration based on ULC data. 
In 2014 the central airport of Frederic Chopin in Warsaw handled over 39\% of all passengers. Among the regional airports in Poland by far the most important role played the ports in Krakow, Gdansk and Katowice. In these three cities, the ports served in $201436 \%$ of passengers (while it was $59 \%$ of all passengers using regional airports). Quite important for regular passenger traffic were also the ports in Wroclaw, Poznan and Modlin. An interesting case in point is the airport in Modlin, which just four years after putting into use has already gained more than $6 \%$ share in the segment of regional airports. Other airports in Poland are rather marginal in the overall structure of regional airports - in 2014 their combined share in total number of passengers handled amounted to less than $6 \%$.

The study of development of airports in Poland was expanded to include an analysis of the carriers operating in these ports. The reference will allow better understanding of the trends and causes of change in the structure of airports in Poland. Figure 3 shows the major carriers operating on the Polish market in 2014, while in Figure 4 a comparative analysis of the participation of Polish traditional as well as foreign low-cost carriers in Polish aviation market was presented.

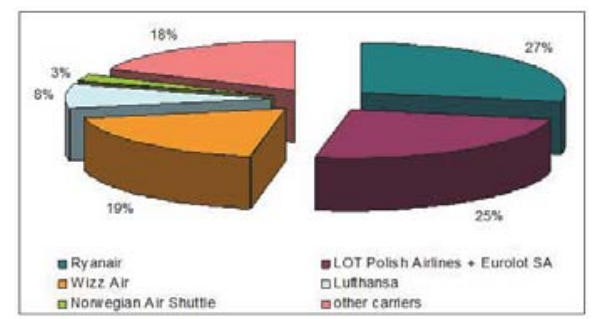

Figure 3: Major carriers on the Polish aviation market in 2014

Source: Own elaboration based on ULC data.

In 2014, the biggest share in the aviation market in Poland recorded Irish Ryanair, which handled more than $1 / 4$ of all passengers. Not much worse result was achieved by Polish airlines LOT. It is worth noting that the five largest carriers in 2014 included as many as 3 low cost carriers: Ryanair, Wizz Air, and Norway Air Shuttle, who covered almost half the market. It shows to which extent Polish aviation market 10 years after liberalization was virtually dominated by the LCC carriers. For comparison, you can add here that in 2005 the largest market share had LOT (43.81\%) and foreign carriers handled in total $51.37 \%$ of the passengers, while the share of foreign carriers in the market stood at $26.33 \%$. In 2010 again the largest market share had LOT (including EUROLOT) - the share was 31.24\%. The next two positions occupied low cost carriers: Ryanair (with a share of 21,61\%) and Wizz Air (20.69\%). Five major carriers complemented Lufthansa (7.58\%) and EasyJet (2.90\%).

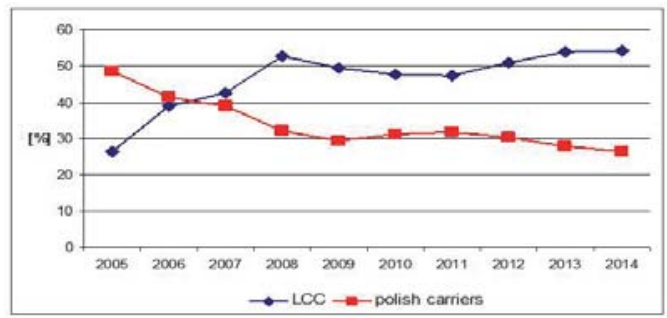

Figure 4: Participation of Polish traditional carriers and low-cost carriers in the aviation market in Poland Source: Own elaboration based on ULC data.

The tendencies shown on the chart confirm the thesis given earlier that low cost carriers dominated Polish market. As early as three years after the entry into this market, they serviced more passengers than the traditional Polish companies, led by the company LOT. The difference in market share of these two groups of carriers increasingly deepens, as the share of low-cost carriers continues to rise (except for 2009-2011), and Polish carriers - to decline (except for 20102011). This rapid growth of LCC carriers would not have been possible without the network of regional airports. It is these ports which are in fact assumed to be the base of many low-cost carriers. 


\section{The dynamics of the development of selected European airports and regional airports in Poland}

European aviation market in 1997 already underwent liberalization and the introduction of the policy of "open sky". Therefore, much earlier than in Poland, low cost carriers were introduced to it, who primarily selected regional airports for their bases. In many European countries we deal with a situation when in a short distance from the central airports, develop regional airports, which are bases for numerous major LCC carriers. Figure 1 shows the dynamics of such pairs of ports in selected cities. The central airports include: Brussels Airport, El Prat, Charles de Gaulle and Heathrow, while Charleroi, Girona, Beauvais and Luton are regional ports, being the hubs of large low cost carriers.

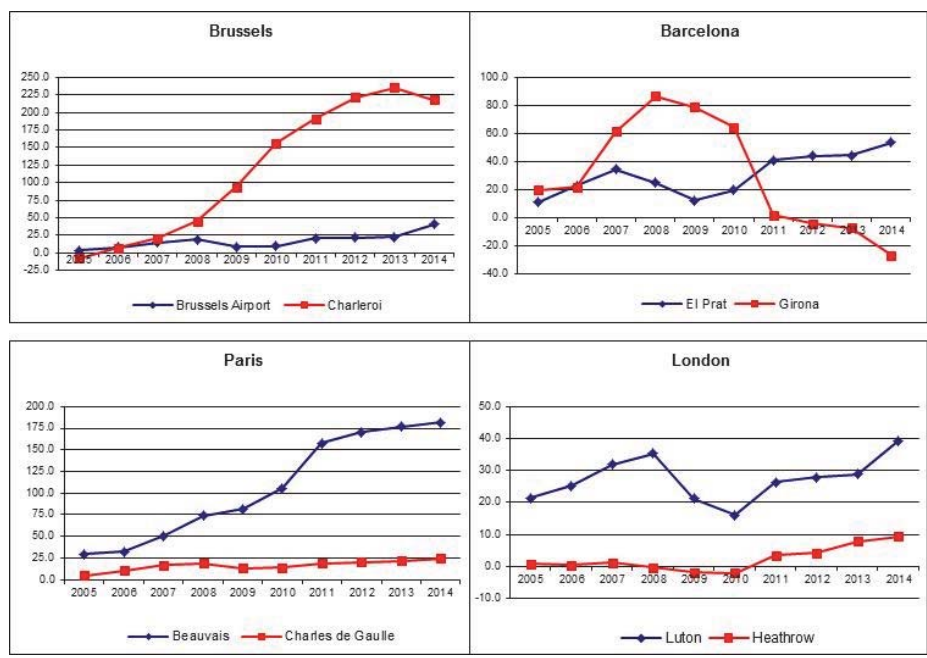

Picture 1: Dynamics of the number of passengers served in selected European airports (2004 = base year)

Source: Own elaboration based on Eurostat data.

Growth rate in passenger numbers for each city is highly diversified. An interesting case is the port of Girona, which since 2011 has recorded a steady decline in the number of passengers served, achieving a negative level of the analyzed indicator. Such a situation is not isolated in the Spanish regional airports, because many of them are struggling with the same problem. What is, however, unique in Europe, is the fact that the largest low cost carriers (including Ryanair) prefer the central airport, which is El Prat to a regional airport in Girona, because of favourable conditions of cooperation.

In case of the other analyzed cities, significantly higher dynamics in the terms of number of passengers had regional airports. The record here is the airport of Charleroi, for which the index growth rate was over $220 \%$. Number of passengers serviced at central airports was growing much more slowly. Overview of the development of European airports was extended to analyze the development of Polish air transport aviation market. First, the dynamics of the development of regional airports and the central port against the background of average rate of growth of the aviation market in Poland were compared, which is presented in Figure 5. The base year was declared the year 2004.

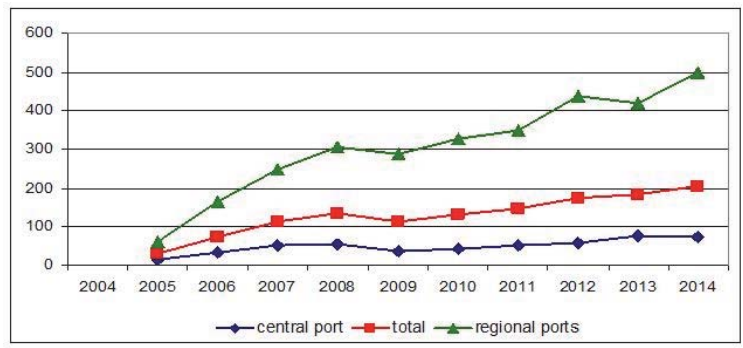

Figure 5: The dynamics of the number of passengers in aviation traffic in Poland in 2005-2014 (2004=base year) Source: Own elaboration based on ULC data. 
Much bigger dynamics of passenger numbers recorded regional airports rather than the central port. While at regional airports this rate in 10 years reached almost 500\%, in the central port the number of passengers handled increased by almost 100\%. This means that the ports in the region developed more than 5 times faster than the central port.

The analysis of the overall dynamics of regional airports complements the study of the dynamics of selected regional airports. This activity is shown in Figure 6. Similarly, as in the previous case, 2004 was assumed base year.

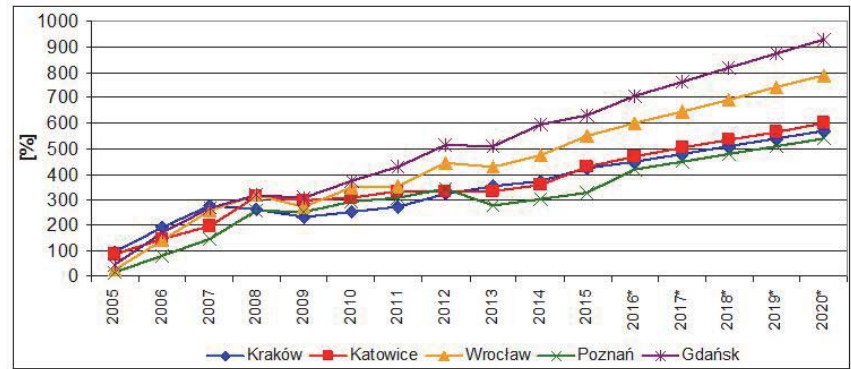

Figure 6: Dynamics of the number of passengers served in selected regional airports in Poland in 2005-2020 (2004 = base year; for years 2016-2020 there are the forecast values)

Source: Own elaboration based on ULC data.

The analyzed airports are characterized by high growth in number of passengers. During the 10-year-period, all the airports recorded a significant increase in the number of passengers: from about 3-fold increase of this number in case of the port in Poznan, up to approx. 6-fold increase in case of the port of Gdansk. In the years 2009 and 2013 in almost all of the analysed airports, there were slight decreases in number of passengers compared to the previous years, but this trend was short-lived one.

Basing forecasting of the development of regional airports on analytical models of the trend it is possible to suppose that in the near future we will be dealing with further systematic growth of the number of passengers handled by individual airports. In 2020 in each of analyzed airports at least 5 times more passengers will be handled than in 2004, but in the case of the port in Gdańsk it will be as far as 9 times more passengers. The forecast rate of growth is fastest for airports in Gdańsk and Wrocław. At present all ports are far from exploiting the full bandwidth, what means that the demand for services of the passenger air transport forecasted for the nearest years will be able to be satisfied at exploiting the current infrastructure. Of course, however, increasing the bandwidth is necessary in the longer temporary prospect. Remembering that the investment processes associated with the infrastructure of airports are quite timeconsuming, in case of some ports discussion in this subject should already now begin.

Generally it can be assumed that in all these airports the dynamics developed in a similar manner. As already mentioned, one of the main driving forces in the development of regional airports is the presence of these low-cost carriers. In this context, it seems interesting to compare the number of destinations available from the airports offered by individual carriers. For the analysis, two major carriers of Polish LCC market, Ryanair and Wizz Air, were selected. The number of directions of the flight offered in each airport with the division on carriers is presented in Figure 7.

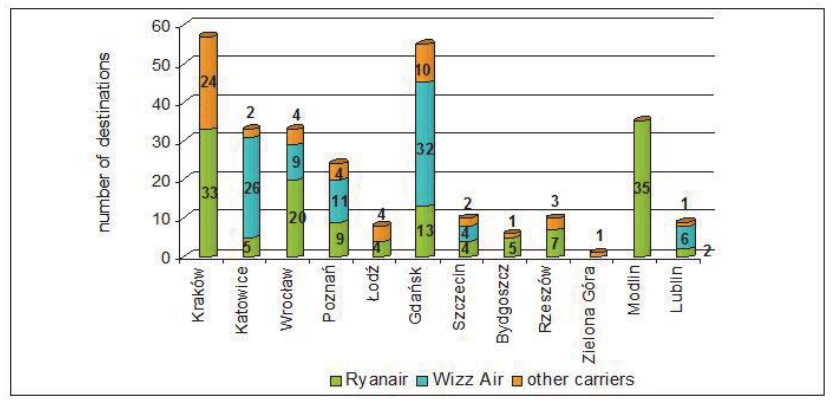

Figure 7: Number of flight directions offered by the carriers in different airports in October 2015 Source: Own elaboration based on the data of Ryanair, Wizz Air and other airports 
The plotted data clearly show that the development of regional airports is closely related to the presence of low-cost carriers. Among all Polish regional airports, only in Krakow the other carriers have a relatively large share of the total destinations. In other cases, Ryanair and Wizz Air operated the vast majority of flights. An interesting case is once again the airport in Modlin, which offers more than 30 directions of the flight, while it is only the hub of Ryanair carrier. In this port operates only one carrier, yet Modlin had in 2014 more than 6 percent share in the aviation market (measured by the number of passengers handled in regional traffic).

Zielona Góra is the only airport in Poland, where Ryanair does not operate. The port is not used by the Wizz Air, either. The lack of two largest LCC carriers makes the port in Zielona Gora in Poland of marginal importance. Wizz Air has decided also not benefit from such airports as Lodz, Krakow, Rzeszow, Bydgoszcz and Modlin. Unlike Ryanair, Wizz Air, however, flies from the central port of Warsaw.

The data indicate that Polish regional airports are dependent on the two LCC carriers: Ryanair and Wizz Air. This phenomenon is dangerous because the carriers are aware of their dominant position, and can push on the airports in order to obtain better conditions. In extreme cases, they can go as far as economic blackmail, to which Polish airports often acquiesce, knowing that without the LCC carriers they may become unprofitable and lose their importance.

Assessing action and the development of regional airports in Poland it is worthwhile to consider, which of these ports play an important role in the Polish air transport. For that purpose the multi-criterial analysis method was applied, in which individual criteria can assume values in from 1 to 6 , where: 6 marks the highest evaluation, and 1 - the lowest. Only airports handling over 1 million passengers annually were analyzed. For a good assessment, importances corresponding to their importance were assigned to criteria. Results of an analysis were presented in table 1.

Table 1. Multi-criterial analysis of regional airports handling over 1 million passengers annually

\begin{tabular}{|l|c|c|c|c|c|c|c|}
\hline & Weight & Kralḱw & Katowice & Wrocław & Pozmań & Gdańsk & Modlin \\
\hline Number of passengers & $\mathbf{0 , 2 2}$ & 6 & 4 & 2 & 1 & 5 & 3 \\
\hline Number of carriers & $\mathbf{0 , 0 9}$ & 6 & 3 & 3 & 3 & 4 & 1 \\
\hline Number of destinations & $\mathbf{0 , 2}$ & 6 & 4 & 4 & 2 & 6 & 4 \\
\hline Area of ter minals & $\mathbf{0 , 0 4}$ & 6 & 4 & 2 & 4 & 5 & 1 \\
\hline Capacity & $\mathbf{0 , 2}$ & 6 & 4 & 2 & 2 & 5 & 2 \\
\hline Number of check-in desks & $\mathbf{0 , 1 1}$ & 5 & 5 & 3 & 3 & 3 & 3 \\
\hline $\begin{array}{l}\text { Relation of check-in desks } \\
\text { to number of passengers }\end{array}$ & $\mathbf{0 , 0 8}$ & 3 & 5 & 4 & 6 & 2 & 3 \\
\hline $\begin{array}{l}\text { Number of parking places } \\
\text { for planes }\end{array}$ & $\mathbf{0 , 0 6}$ & 3 & 5 & 2 & 3 & 6 & 2 \\
\hline Weighted average & $\mathbf{1}$ & $\mathbf{5 , 4 7}$ & $\mathbf{4 , 1 6}$ & $\mathbf{2 , 7 6}$ & $\mathbf{2 , 4 4}$ & $\mathbf{4 , 7 1}$ & $\mathbf{2 , 4 6}$ \\
\hline
\end{tabular}

Source: own study based on airports information

Airport in Cracow has definitely the most important meaning out of regional airports in Poland. It achieves the highest results of largely analyzed parameters, in it in particular in issues assessed as most important. Also ports in Gdańsk and Katowice play an important role amongst Polish airports. What is interesting, the port in Gdańsk comes out most poorly of all ports in the issue of the relationship of check-in stands to the number of served passengers. And so it is a parameter, over improvement of which the administrators of the airport should think. Improving of it is not a particularly difficult task, because it will be sufficient to increase the number of check-in stands. Taking increasing trends in the number of passengers handled annually by the airport into consideration, in the near future such a solution can already turn out to be essential to keep the appropriate quality of the passengers service.

Out of analysed ports Poznań and Modlin are least essential for the passenger air movement. The port in Modlin was being built relatively recently (moreover only one carrier operates there at present), and already managed to be in a group of airports handling over 1 million passengers annually (in 2015 over 2,5 million passengers were handled there). Obserwing the development of this port it is possible to forecast that its meaning amongst regional airports in Poland will grow. It is necessary, however, to consider the fact that the capacity of the airport was exploited in over $80 \%$, and so without next investments keeping current dynamics of the development will be impossible.

Generally it is possible to state that analyzed regional airports in Poland are divided into two groups. Ports in Cracow, Gdańsk and Katowice, which in above analysis were assessed well or very well, constitute the first group. These ports (next to the central port in Warsaw) have most meaning in the handling of the air passenger traffic in Poland. The second group, i.e. ports in Wrocław, Poznań and Modlin, is already definitely less crucial however it does not mean, that these ports are not needed. Just the opposite - the development of these smaller airports provides the improved accessibility of the air transport and its growing importance.

At the end it must be added that to ensure that regional airports can efficiently develop and become increasingly 
important, also on a European scale, adequate infrastructure is necessary. This is mainly road and rail infrastructure, ensuring easy communication with the region. In Polish realities this condition, unfortunately, is still not satisfied. It is true that this issue seems better than a few years ago, but still the majority of airports are poorly connected to multimodal infrastructure. The best transport accessibility can be noted for the following airports: in Katowice (having a connection with the S1 expressway), Gdansk (connected with express road S6), Krakow (having an exit from the A4 motorway and rail links to the city center), Wroclaw (located near Wrocław Ring Road) and Modlin (which has rail links to the city center and the central port). They not coincidentally are exactly the same regional airports that serve the greatest number of passengers, and have the widest range of directions of the flights. It is thus clear relationship between transport accessibility of the airport and its popularity measured by the number of passengers and the range of available travel destinations.

\section{Summary}

The liberalization of the aviation market in Poland, resulting in admission to trading low cost carriers, was the first step toward the development of regional airports. It was the LCC carriers who are the stimuli for regional airports to develop and improve their effectiveness of operation. Most of Polish ports made good use of this stimulus, within 10 years, noting even several fold increase in the number of passengers. As a result, regional airports took over from the central port the major role in the development of the aviation market in Poland and providing its steady growth. Maintaining the current rate of development allows the largest Polish airports to compete with regional airports in other European countries. The development of airports is also a great opportunity for the regions in which these ports are located, increasing their attractiveness and availability of tourism, generating new jobs and affecting the overall socio-economic situation (Marek \& Liszewski, 2015, Nowak \& Ulfik, 2014).

Polish "free aviation market" is still relatively young and fairly absorbent, so it is now when regional airports should intensify their efforts to attract and retain not only the passengers, but mainly the carriers. Today, it is generally too large dependence of regional airports on two foreign LCC operators, which are Ryanair and Wizz Air. These carriers in 2014 had in their hands more than $45 \%$ of the total aviation market in Poland, being at the same time the main partner of most regional airports. Such a dominant position, as well as the competitive struggle between ports, allows the carriers to dictate the terms of cooperation, which in extreme cases may end up with the financial losses of the airports. Cooperation with more carriers can provide airport a little more independence, while leading to further development. There, the airports should draw from the experience of regional airports of other European countries, which often had to settle for unfavorable for them terms of cooperation, so as not to lose contracts with low-fare carriers and not to expose them to fall.

However, to be able to attract new partners, regional airports have to deal with an important issue, which is poor accessibility. Airports that do not have adequate road and rail connections with nearby urban centers, are not able to attract passengers, and hence - new carriers. Therefore, one of the main challenges currently faced by regional airports is to improve their communication accessibility, so as not to stand out from European standards. Improving the accessibility largely depends, however, on the decision of the central authorities, which is why airports have a limited impact on this issue

\section{References}

Anduena Gjevori LL. M. (2013). The Rights of Albanian Nationals under the Stabilization and Association Agreement between Albania and the European Communities. Mediterranean Journal of Social Science, 4(1), 439-446.

Augustyniak W. M. (2012). The effectiveness of Polish regional airports. Doctoral dissertation. [In Polish] [Online] Avaliable: http://www.wbc.poznan.pl/Content/../Augustyniak_Wojciech_Efektywnosc.pdf (October 10, 2015)

Ballart X., Güell C. (2015). Airport ownership and regulation in Spain: Explaining the resistance to change. Journal of Air Transport Management, 47, 112-118.

Barbot C. (2006). Low-cost airlines, secondary airports, and state aid: An economic assessment of the Ryanair-Charleroi Airport agreement. Journal of Air Transport Management, 12, 197-203.

Barros C. P., Liang Q. B., Peypoch N. (2013). The efficiency of French regional airports: Aninverse B-convex analysis. International Journal of Production Economics, 141, 668-674.

Carballo-Cruz F. (2014). Success factors of regional airports: The case of Oporto airport. Tourism \& Management Studies, 10(1), 37-45.

Czecharowski S. (2002). Polish regional airports after a few years. Przegląd komunikacyjny, 7-8, 22-28 [In Polish].

Gomez Comendador F., Arnaldo Valde R. M., Perez Sanz L. (2012), Liberalisation of AirTraffic Services in Spain. Transport Policy, 19, 47-56. 
Graham B. \& Shaw J. (2008). Low-cost airlines in Europe: Reconciling liberalization and sustainability. Geoforum, 39, $1439-1451$.

Halpern N., Pagliari R. (2007). Governance structures and the market orientation of airports in Europe's peripheral areas. Journal of Air Transport Management, 13, 376-382.

Humphreys I., Francis G. (2002). Policy issues and planning of UK regional airports. Journal of Transport Geography, 10, $249-258$.

Ison S., Francis G., Humphreys I., Page R. (2011). UK regional airport commercialisation and privatisation: 25 years on. Journal of Transport Geography, 19, 1341-1349.

Karas, L., Ferencova, M. (2010) The Survey of Attitudes of Students of Management Toward Travel Tour Prices. Polish Journal of Management Studies, 2, 172-178.

Kot, S. (2015) Cost Structure in Relation to, the Size of Road Transport Enterprises, Promet - Traffic \& Transportation, 27(5), $387-394$.

Litwiński J. (2009). Airport operations in 2009. Warszawa: Urząd Lotnictwa Cywilnego [In Polish].

Marek, M., Liszewski.D. (2015). Development of Polish regional airports in the context of tourism needs. Polish Journal of Management Studies, 11(1), 90-99.

Nowak, S., Ulfik, A. (2014). An evaluation of regional development in the context of economic and environmental benefits. Polish Journal of Management Studies, 10(1), 74-83.

Núńez-Sánchez R. (2015). Regional public support to airlines and airports: An unsolved Puzzle. Transportation Research Part E 76, 93107.

Olebogeng A. B., Olebogeng D. D. (2013). The Determinants of Domestic Air Passenger Demand in the Republic of South Africa. Mediterranean Journal of Social Sciences, 4(13), 389-396.

Postorino M. N. (2010). Development of regional airports in EU. W: M. N. Postorino (ed.), Development of Regional Airports. Theoretical Analyses and Case Studies (27-52). Southampton: WIT Press.

Rekowski M. (2011). Regional airports in Poland. Characteristics and trends. Poznań: Wydawnictwo Uniwersytetu Ekonomicznego w Poznaniu [In Polish].

Suau-Sanchez P., Burghouwt G. (2011). The geography of the Spanish airport system: spatial concentration and deconcentration patterns in seat capacity distribution, 2001-2008. Journal of Transport Geography, 19, 244-254.

Szymonik A. (2013). The economics of transportation for logistics. Warszawa: Diffin [In Polish].

Tapiador F. J., Mateos A., Marti-Henneberg J. (2008). The geographical efficiency of Spain's regional airports: A quantitative analysis. Journal of Air Transport Management, 14, 205-212. 